\title{
A METHOD OF MEASURING THE RATE OF CONDUCTION OF NERVE
}

\author{
MASAMICHI ICHIOKA* \\ Department of Physiology, Tokyo Medical and Dental University, Tokyo
}

Since the work of Hermann on the action current of muscle, it has been believed to be certain, that the record of a diphasic action current of nerve and muscle, led off bipolarly, is the algebraic sum of two monophasic records to be taken at each electrode separately. By making the electrode distance larger than the so-called "Aktionslänge" (1), two monophasic action current curves, oppositely directed and separated by the zero-potential line can be recorded. The time interval $(T)$ between the starting points of these two monophasic deflections corresponds to the conduction time of the fastest negativity wave for the distance $(D)$ between the two electrodes. We shall thus be able to evaluate the mean rate of conduction of the fastest negativity wave, from the ratio $D / T$.

\section{METHOD}

A longest possible stretch of a sciatic nerve (about $70-80 \mathrm{~mm}$.) was cut out from the toad (Bufo vulgaris). A pair of stimulating electrodes of silver wire $\left(E_{1}, E_{2}\right.$ in fig. 1$)$ was placed at the central part, through which a constant current pulse of an about $3 \times 10^{-5}$ sec. duration, provided by the "Punktkontakt" (2) of Helmholtz' pendulum, and of the just maximal strength was delivered in downward direction. One of the leading electrodes of silver $\left(E_{3}\right)$ was placed about $10 \mathrm{~mm}$. distal from the cathode of the stimulating electrodes, while the other electrode $\left(E_{4}\right)$ at various distances $(50-70 \mathrm{~mm}$.), which are longer than the so-called "Aktionslänge," from the electrode $E_{3}$. The action currents were recorded by means of a R.C.-coupled amplifier and an oscilloscope.

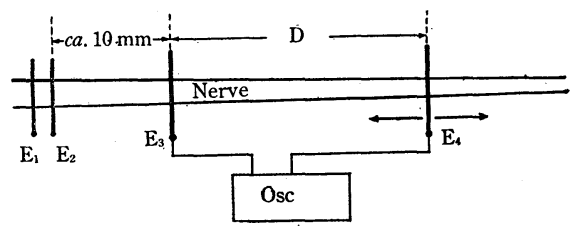

FIG. 1. Experimental arrangement. $E_{1}$, $E_{2}$ : Stimulating electrodes ( $E_{2}$, cathode). $E_{3}$, $E_{4}$ : Leading electrodes. $D:$ Distance between two leading electrodes (variable).

\section{RESULTS AND DISCUSSION}

The record of the action current thus obtained was not so simple as was expected. The separation of the upward and downward deflections, due to the

Received for publication December 4, 1953.

*方戌正道 
excitations under the two electrodes respectively, was not always made by the zero-potential line, but generally by a short piece of line, lying above or below, and inclined variously to, the line of zero-potential niveau, which resulted in making the whole configuration appear rather polyphasic (fig. 2). A question then arose as to where the second deflection really started downwards. However, after examinations of all the records obtained, they could be classified into six types, as illustrated in fig. 3 , and the author decided to take the points iudicated by the arrows in the figure as the starting points in question. The reasons are as follows:

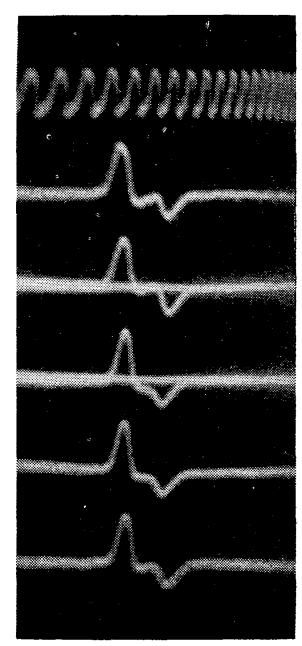

\begin{tabular}{cc}
\multicolumn{2}{c}{1,000 cps. } \\
$D($ in mm. $)$ & $\mathrm{V}(\mathrm{m} / \mathrm{sec})$. \\
63.0 & 24.2 \\
56.2 & 22.0 \\
50.0 & 23.9 \\
52.2 & 24.4 \\
56.1 & 24.2
\end{tabular}
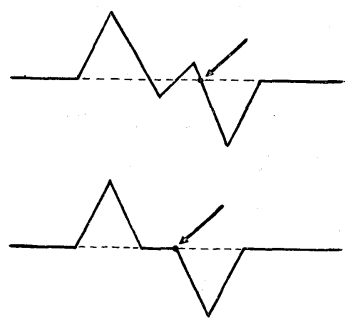

FIG. 2 (left). Action currents led by a pair of electrodes widely apart. $\left(21.3^{\circ} \mathrm{C}\right.$.

FIG. 3 (right). Six types of the configuration of the records, half schematic. Arrows indicate the assumed starting points of the excitation under the distal electrode.
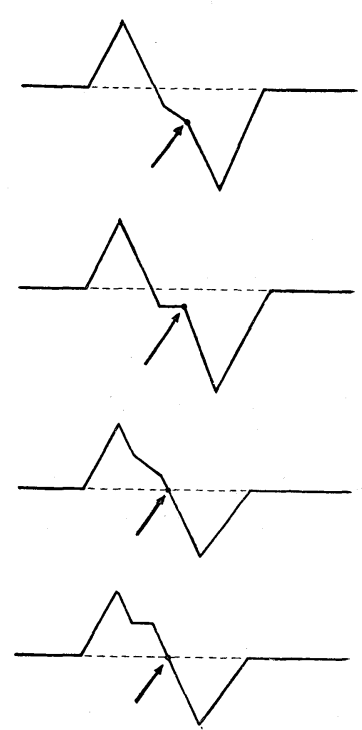

i) There must be some "action at distance" being exerted by the propagating wave and affecting the potential of the distal electrode, though not so much as in Craib's experiments (3) where the materials (sartorius muscles) were placed in a wide field of fluid. The apparent polyphasicity of the records obtained in the present experiments must be due to this field effect produced by the excitation wave in propagation.

ii) The genuine starting point of the second (downward) deflection should lie on or below the zero-potential line, according to whether there is a field effect or not. At this point, the distal electrode is to be freed from the field 
effect, and hence its potential should fall abruptly, to result in producing a straight downward deflection.

Standing on such a reasoning, the rate of conduction of nerve was measured in various conduction distances $(D)$ and compared with the results obtained by the usual method, that is, the method of recording two monophasic action currents at two different points. The results obtained in various distances

TABLE 1

\begin{tabular}{|c|c|c|c|c|c|}
\hline $\begin{array}{l}\text { No. of } \\
\text { experi- } \\
\text { ments }\end{array}$ & $\begin{array}{c}\text { Temper- } \\
\text { ature } \\
\left({ }^{\circ} \mathrm{C} .\right)\end{array}$ & $\begin{array}{c}\text { Distance } \\
(\mathrm{mm} .)\end{array}$ & $\begin{array}{c}\text { Conduction } \\
\text { time } \\
\text { (msec.) }\end{array}$ & $\begin{array}{l}\text { Cond. veloc. } \\
\text { obtained by } \\
\text { this method } \\
(\mathrm{m} / \mathrm{sec} .)\end{array}$ & $\begin{array}{l}\text { Cond. veloc. } \\
\text { obtained by } \\
\text { the usual } \\
\text { method } \\
(\mathrm{m} / \mathrm{sec} .)\end{array}$ \\
\hline \multirow[t]{2}{*}{1} & 20.8 & $\begin{array}{l}55.5 \\
55.5 \\
65.0 \\
65.0 \\
62.3 \\
52.3 \\
57.0 \\
65.3\end{array}$ & $\begin{array}{l}2.11 \\
2.16 \\
2.61 \\
2.47 \\
2.21 \\
2.36 \\
1.90 \\
2.22\end{array}$ & $\begin{array}{l}26.3 \\
25.5 \\
24.9 \\
26.3 \\
28.2 \\
26.4 \\
30.0 \\
29.4\end{array}$ & \\
\hline & & & & 27.12 & \\
\hline \multirow[t]{2}{*}{2} & 21.3 & $\begin{array}{l}52.0 \\
55.0 \\
50.0 \\
50.0 \\
47.0 \\
56.1 \\
52.2 \\
50.0 \\
56.2 \\
63.0\end{array}$ & $\begin{array}{l}2.25 \\
2.26 \\
2.07 \\
2.17 \\
1.91 \\
2.31 \\
2.14 \\
2.09 \\
2.55 \\
2.60\end{array}$ & $\begin{array}{l}23.1 \\
24.3 \\
24.2 \\
23.0 \\
24.6 \\
24.2 \\
24.4 \\
23.9 \\
22.0 \\
24.2\end{array}$ & \\
\hline & & & & 23.79 & \\
\hline \multirow[t]{2}{*}{3} & 21.0 & $\begin{array}{l}47.8 \\
50.0 \\
53.0 \\
50.8 \\
49.4 \\
51.9\end{array}$ & $\begin{array}{l}1.91 \\
2.16 \\
1.93 \\
1.77 \\
1.71 \\
1.83\end{array}$ & $\begin{array}{l}25.0 \\
23.1 \\
27.5 \\
28.7 \\
28.9 \\
28.4\end{array}$ & \\
\hline & & & & 26.93 & 26.5 \\
\hline \multirow[t]{2}{*}{4} & 21.0 & $\begin{array}{l}42.1 \\
43.0 \\
44.2 \\
44.0 \\
52.2\end{array}$ & $\begin{array}{l}1.73 \\
1.79 \\
1.67 \\
1.76 \\
1.91\end{array}$ & $\begin{array}{l}24.3 \\
24.0 \\
26.5 \\
25.0 \\
27.3\end{array}$ & \\
\hline & & & & 26.35 & 26.2 \\
\hline \multirow[t]{2}{*}{5} & 21.2 & $\begin{array}{l}55.1 \\
52.0 \\
50.0 \\
44.5\end{array}$ & $\begin{array}{l}2.10 \\
2.01 \\
2.02 \\
1.67\end{array}$ & $\begin{array}{l}26.2 \\
25.9 \\
24.8 \\
26.7\end{array}$ & \\
\hline & & & & 25.90 & 25.0 \\
\hline
\end{tabular}


agreed fairly well with each other, and also with those obtained by the method usually employed (table 1).

A drawback of the present method is that the nerve as material must be sufficiently long, so as the electrode distance can be longer than the "Aktionslänge." In fact, however, the nerve is not always so long. Another point to be noted is that the experiments must be performed under properly high temperatures, because the low temperature brings forth the separation of the compound action current curve into components of different velocities.

Thus, the method adopted in the present work can not always be said to be superior to those hitherto employed. There is, however, a great advantage that the measurement can be carried out by means of a single recording, without regard to the spread of the stimulating current.

In the experiments described above, the "Aktionslänge" was assumed to occupy about 40-50 mm., as has been generally believed (Schaefer, (1); Hill, (4)). This means that the duration of the electrical activity at a point of nerve was taken to be so short as $2 \mathrm{msec}$. or so. Sugi (5) claims, based on his experiments performed with his "separation method," that the duration of a monophasic action current of the sartorius muscle of frog is so long as several hundreds msec. and, therefore, the "Aktionslänge" of muscle should be $50 \mathrm{~cm}$. or more. He thinks that it will be the same in the case of nerve, too. The present author believes, however, that, as far as the nerve is concerned, the duration of the monophasic action current in propagation is not longer than a few msec. at a point, from the following reasons:

i) The conduction velocity of nerve estimated by the present method in various conduction distances agreed fairly well with each other, as seen in table 1. This fact indicates that the two main deflections, upwards and downwards, in each record in fig. 2, are nothing but the expressions of excitations taking place under the one and the other electrodes.

ii) Tasaki's well-known records of uninodal action current are all of $2-3$ msec. durations. In his method, it is certain that the record represents the temporal course of the electrical activity of an excited node.

iii) Recently, after a number of careful experiments, Uchizono (6) and Wakabayashi and Iwasaki (7) have reached the conclusion that the duration of the monophasic action current of toad nerve is not so long as claimed by Sugi.

\section{SUMMARY}

1. A method of measuring the rate of conduction of nerve by means of a single recording of a diphasic action current was described. The material was wanted to be long enough, so as the electrode distance could be larger than the "Aktionslänge."

2. Six types were found to appear in the configuration of the action current thus recorded, yet the right estimation of the velocity seemed possible, if the starting point of the deflection due to the excitation under the distal electrode, was properly determined.

3. A few notes as to the application of the method was described. 
The author wishes to express his sincere gratitude to Prof. K. Yamagiwa for valuable suggestions and helpful criticism.

The expenses for this work were defrayed by a grant from the Ministry of Education of Japan.

\section{REFERENCES}

1. Schaffer, H. Elektrophysiologie, I : 288. Wien: Franz Deuticke, 1940.

2. HozAw A, S. Die "Anfangszacke" des elektrischen Stromes durch den Menschenkörper, betrachtet als Ladungserscheinung der Polarizationskapazität der Haut. Pflügers Arch. ges. Physiol. 219 : 111-140, 1928.

3. Craib, W. H. A study on the electrical field surrounding skeletal muscle. J. Physiol. $66: 94-73,1928$.

4. Hill, A. V. Chemical Wave Transmission in Nerve, p 16. Cambridge: Cambridge Univ. Press, 1932.

5. SUGI, Y. On the shape of the action current. Its consideration by means of asymmetric lead. J. Physiol. Soc. Jap. (Japanese) 15: 79 P, 1953.

6. UCHIZONO, K. Personal communication.

7. WAKABAYASHI, T. AND S. IWASAKI. Personal communication. 